\title{
The relation between Hebrew and Turkic in Crimean Karaim literature on the basis of a translation of the Hebrew drama Melukhat Sha'ul
}

\author{
Dorota Smętek
}

Adam Mickiewicz University

\begin{abstract}
This paper discusses three topics related to a Crimean Karaim translation of the Hebrew drama entitled Melukhat Shaul. The translation was made in the first half of the nineteenth century, approximately in the 1840s, by a Karaim scholar named Abraham ben Yashar Lutski. The first part of this article is devoted to the characteristics of relations between the Karaims and the Rabbanites at the turn of the eighteenth and nineteenth centuries in the context of their literary activity. It is followed by a short description of the plot of the drama and its connections and deviations from the biblical events presented in The First Book of Samuel. The third part of the article analyzes the influence of Hebrew on the language of the Crimean Karaim translation of Melukhat Shaul. Moreover, attention is drawn to the manner in which Hebrew vocabulary related to magic was translated into Turkic. For the purpose of this paper magical terms, which are present in the Hebrew drama, are compared with their counterparts in the Turkic translation.
\end{abstract}

\section{Keywords}

Crimean Karaim, Melukhat Sha'ul, Hebrew drama, Abraham Lutski, Ha-Efrati

\section{The maskilim and the Karaims}

Before discussing the specifics of the Turkic translation, circumstances under which a maskilic drama Melukhat Sha'ul found its way to the Crimean Karaim community should be analyzed. Throughout the centuries, relations between 
the Karaims and the Rabbanites were of an ambiguous nature. Acts of mutual animosity are as well documented as is evidence of a peaceful coexistence. At the time when Melukhat Sha'ul and its Turkic translation were written, that is in the late eighteenth century and in the first half of the nineteenth century, East European Karaim communities were not on amicable terms with the Ashkenazim. However, they established friendly relations with an innovative group within the Rabbanite majority, namely with the maskilim. ${ }^{1}$ As it is commonly known, this group was inspired by the European Enlightenment movement which claimed that contemporary society had a chance to develop only by the means of widespread education and rational thinking. Thus, it promoted science and opposed the dominating role of the church, which had been obstructing development of secular academic life. As European society was changing and undergoing the process of secularization, intellectual circles within Ashkenazi J ews, that is the maskilim, were inspired by the European rational way of thinking. Consequently, attempts were made to adjust the way of life of their Jewish brethren to the modern European environment. Yiddish, the language of Ashkenazi J ews, was regarded as one of the factors that augmented the gap between Ashkenazim and other Europeans. As a result, the maskilim considered it as inferior to biblical Hebrew, because the latter had attracted the attention of European scholars (WAXMAN 1960: 86-87). The group attempted to develop Hebrew so that it would serve as a tool of their literary activity.

As is well known, the group of maskilim was small in numbers. Nevertheless, it brought a breath of fresh air to Ashkenazim. Growing interest in the holy language of the Torah bore its fruits and the first maskilic literary works appeared in the second half of the eighteenth century. The drama Melukhat Sha'ul is considered to be one of these early works. It was written in biblical Hebrew by Joseph Ha-Efrati Tropplowitz and is described as "the first modern Hebrew drama of the Haskalah period" (SкоLNiк 2007: 195). It should be noted that the author intended to use pure biblical Hebrew; however there appear a number of unintended mistakes and words characteristic of the language of the Talmud.

${ }^{1}$ For further reading see KIzILOv 2009: 202-233. 
The first edition of the play was printed in Vienna in 1793. About fifty years later, in 1840s, it was translated into vernacular Crimean Turkish by Abraham Lutski. The question arises as to how the Karaim scholar gained access to the original play.

\section{Origin of the drama Melukhat Sha'ul}

Initially, I assumed that the play was obtained during Lutski's stay in Istanbul, where hestudied the Talmud and classics of Rabbinic literature for several years. However, while examining available versions of the Hebrew original drama I encountered a Vienna edition of the play, which was published in 1829. I chose this volume for my further research. Surprisingly enough, an important connection was found between the Vienna edition of the play and its Turkic translation.

The title page of the Vienna edition reads as follows: "Melukhat Sha'ul haMelekh ha-Rishon al Yeshurun by Yosef Ha-Efrati Tropplowitz. Printed in Vienna by Anton Edler von Schmid private printer and bookseller in the year 1829". The same printer, Anton Edler von Schmid, co-operated with the Galician Karaims. As shown by Kizilov, this printer published in Vienna in 1830 a compilation of various Karaite literary works entitled Dod Mordekhai (KIzILov 2009: 225). Among other works, the volume included two works written by the Galician-Volhynian Karaims. Both Melukhat Sha'ul and Dod Mordekhai have the identical signature of the publisher, i.e. "Anton Edler von Schmid k. k. priv. Buchdrucker". Thus, it can be concluded that the same printer was involved in publishing of maskilim as well as Karaim literary works. At that time, relations between the Western Karaims and the maskilim were far more friendly than those with the rest of the Rabbanites. The maskilim got interested in the tiny Karaim minorities in East Europe and vice versa, the Karaims were keen to read and study the maskilic literature. Both communities benefited from this rapprochement and they exchanged their literary works.

The Galician Karaims are likely to have obtained a copy of Melukhat Sha'ul in the years in which they maintained close contacts with the Vienna printer. Abraham Lutski, the author of the Turkic translation, was of Volhynian provenance. He emigrated from Lutsk to the Crimean city of Yevpatoria in 1802, 
together with his father J oseph Solomon Lutski (ZAJĄCZKowski 1973: 512-513). Thus, he was not able to obtain the drama personally. After emigrating to the Crimea, both the older and the younger Lutski played prominent roles in the intellectual life of the Crimean Karaim community and authored numerous literary works in Hebrew and Turkic, such as Iggeret Teshu'at Yisra'el or Shivhei Todah, the latter being a compilation of prayers and hymns written together with Abraham Firkovich. The Crimean communities kept up a correspondence with their Galician and Volhynian brethren. Thus, the drama Melukhat Sha'ul must have been brought to the Crimea via the Galician community. It should be stressed that the available data are not sufficient to prove this beyond any doubt due to the fact that the copy of the translated play, which is in my possession, does not have a title page that would provide the required data. Moreover, the colophon written after the main body of the text lacks information concerning the author of translation and any further data with regard to its origin. Nevertheless, the most important aspect of reasoning is that apparently the interest of Karaims in maskilic literature was not limited to Galicia and Volhynia. It was also awakened in the Crimea and inspired further intellectual endeavour in the Crimean Karaim communities.

The appearance of a maskilic drama on the shores of the Crimea and its challenging translation into the literary language of the Crimean Karaims, is one more piece of evidence of the mutual interest and respect of the Karaims and the maskilim in the nineteenth century.

\section{Plot of the drama}

In order to understand the reasons why the Karaims got interested in the Hebrew drama in the first place, we must concentrate on the plot of the drama and the features distinguishing this work from numerous other plays. Melukhat Sha'ul consists of six acts and its plot revolves around biblical events presented in sixteen chapters of The First Book of Samuel, namely from the fifteenth chapter until the thirty-first chapter. We encounter King Saul, the main character of the play, shortly after he had conquered the Amalekites. Nonetheless, he did not feel victorious because he sensed that 
the days of his glory had come to an end. The prophet Samuel approached the king and told him that he had lost the favour of God and soon he would lose his reign over Israel. As a consequence the king's decay, both intellectual and mental, had begun. A young boy named David was summoned to play the violin for the king and to raise his low spirits. David was a sweet boy who has soon become a favourite of the king and the royal children. What is more, he defeated the Philistines and killed the invincible Goliath. Ironically the youngster, who was supposed to help Saul, has become the reason of his greatest fear. The monarch, struck by a fit of madness, started to imagine that David had gained the favor of God and that he would attempt to dethrone him. From this time on Saul's eyes were veiled with madness and he would refuse to listen to sound advices. Therefore, Men intend on intrigue such as Doeg the Edomite began to surround the monarch and gradually his hatred towards David grew stronger. It was not until the fourth act when Saul decided to murder David, who by this moment had become his son-inlaw. If it was not for the young boy's escape to Ramah, the king would have committed a mortal sin. In the final scene of the play king Saul reconciled with David shortly before dying on mount Gilboa.

The drama deviates from the biblical story which was portrayed in The First Book of Samuel. The dramatist attempted to describe the biblical figures of Saul and David with psychological insight, which is absent from the Old Testament. Consequently, Ha-Efrati elaborated on events which were hardly mentioned in the Bible and had a potential to display emotional states of the characters. Among these extended scenes there are prolonged monologues of Saul, such as the one in the second act, in which he loses his mind after being rejected by God. The monarch's words are extremely emotional, filled with sorrow and bitterness, as in the fragment that follows: "Woe, how scary it is to see this man! He will seize the throne of my reign and throw it with anger to the ground. But how terrible are these visions which appear over there. They are enormous, they reach the sky!" (Sме̨тек 2012: 10b). ${ }^{2}$ Another

2 The text in the Bible is concise: "Now the spirit of the Lord departed from Saul, and an evil spirit from the Lord tormented him" (1 Sam 16:14). 
episode, which is absent from the Old Testament, is a dialogue between the members of Saul's family, namely Ahinoam, Abner, Michal, Malchi-shua and Jonathan. This scene was added in the fifth act to emphasize that the king is in poor psychological condition: "Michal and Ahinoam: Tell us, what happened that he [Saul] began to shiver? Abner: Why are you making so much noise? Be patient. He is a bit sad. Didn't you recognize? Malchi-shua: (...) Hurry up, don't stand still. Go to him, to his chamber. Hurry up, his anger is burninglike fire!” (Мме̨тек 2012: 43b-44a).

The most significant aberration from the biblical text is placed in the drama's final scene, which corresponds to the thirty first chapter of The First Book of Samuel. After a lost battle against the Philistines the king was dying from his own sword as he did not want to be killed by the enemy. In that episode the dramatist deviated from the Old Testament narrative by having David appear on mount Gilboa and approach the fatally wounded Saul. The madness withdrew from the king as he understood that David had always been loyal to the throne. In this touching scene Saul apologized to the young boy and called him his son. Thus, the readers may realize that the king's insane behaviour throughout the drama was caused by the unmerciful decree of God.

As it has been shown above, the author extended certain scenes and added a few new ones. At the same time he excluded some episodes such as the anointment of David (1 Sam 16:1-13), David's visit at Nob and Gath (1 Sam 21:2-15) and Saul's slaughter of the priests of Nob (1 Sam 22:6-20). Waxman (1960: 131) argued that the author "omitted some biblical episodes which could have been elaborated into effective scenes" such as the anointing of David. Even if that is the case, the plot woven by Joseph Ha-Efrati is dramatic and poignant. What is more, the episodes selected from The First Book of Samuel successfully demonstrate the psychological development of the main characters.

\section{Language of the drama Melukhat Sha'ul}

The Turkic language of the translation is a variety of Turkic literary language which had been used in the Crimea. Most of its features are shared with Crimean Turkish. However, it is not a standardized language. It is also 
influenced by Crimean Tatar and has a lexical substrate typical of Crimean Karaim. Based on the characteristics of the language it can be concluded that the drama was addressed solely to the Crimean Karaims and was certainly unintelligible to the Galician and Volhynian Karaim communities.

A significant part of vocabulary, which is typical of Crimean Karaim and absent from languages of other Crimean Turkic minorities, has been borrowed or derived from Hebrew. The majority of these words is related to religion, similarly to other Karaim texts translated from Hebrew, there are terms such as Adonay, ben Adam, kohen, qodeş, seder etc. Moreover, Hebrew influence is also to be seen in vocabulary related to magic, even though the influence of Arabic and Persian is far more prominent. The Turkic translation provides us with a variety of lexical material concerning magic. The majority of these examples occur in the scene corresponding to the twenty eighth chapter of The First Book of Samuel, in which Saul consults a medium.

In an article dedicated to magical terms in Karaim translations from $\mathrm{He}$ brew, Dubiński attested that "there are no standardized Karaim equivalents of specific Hebrew words and terms [related to magic]. Yet, we may observe a tendency to translate the original vocabulary accurately, while maintaining a freedom of interpretation" (DuBIŃski 1994: 188). The lack of a standardized terminology is visible when we compare different Crimean Karaim texts preserved in handwritten books called mejumas. Below, I provide a comparison of magical terms, which occur in the Hebrew original drama, with their translations into Turkic. Additionally, respective linguistic material which is to be found in heretofore published mejumas is presented. ${ }^{3}$

\subsection{Comparison of Hebrew magical terms with Turkic counterparts}

In the Hebrew drama the word denoting 'witch' is בעלת אוב 'the female medium who divines by spirit' (HA-EFRATI 1829: 80b) is used. This term occurs in the translation in two variants, that is cadu 'a witch' and cadu qaru 'a female wizard'

3 See Radloff 1896, Aqtay 2009 and Çulha 2010. 
(Sме̨тек 2012: 56b). The former is evidenced in another Crimean Karaim manuscript published by Çulha (2010: 212) in the same phonetic variant. The latter is present in Crimean Karaim texts published by Radloff (1896: 60) in the variant cadu qarı. The word cadu (in Turkish cadl) is a loanword from Persian $\breve{g} \bar{a} d \bar{u}$ and is commonly used in the Turkic-speaking world. It occurs in Crimean Karaim dictionaries in a different phonetic variant, namely caduv (KRPS 171). It is also present in the list of Karaim magical terms attested by Dubiński in the meaning of 'czarodziej, wróżbita | wizard, soothsayer' (DuBIŃski 1994: 186).

The word כשוף 'witchcraft, magic' (HA-EFRATI 1829: 82a) is translated as cadulıq 'witchery, magic' (Sме̨тек 2012: 57a). It is a phonetic variant of the Turkish cadılı and similarly to aforementioned cadu it is commonly used in the Turkic-speaking world. It is present in Dubiński's article concerning magical terms as well as in Karaim dictionaries, for example in Troki Karaim in the variant caduluk (KRPS 171). Nonetheless, it should be noted that dictionaries do not reference it for Crimean Karaim. More importantly, it is present in Crimean Karaim texts published by Radloff (1896: 154).

The Hebrew phrase גבורי כשדים 'Mighty men of the Chaldeans' (HA-EFrAті 1829: 13b) is translated into Turkic in a literal manner as Kasdim'niñ bağaturları 'Chaldean warriors' (Sме̨тек 2012: 10a). The Chaldeans are referred to in the Bible (e.g. Daniel 5:30) as 'astrologists, those who can predict the future'. According to Dubiśski (1994: 182) a derivative of the Hebrew Kasdim, that is kasdimli, which denotes 'a Chaldean person' occurred in Western Karaim translations of the Bible in the meaning of 'przepowiadający, wróżący | soothsayer, foreteller'. This term in also present in Karaim dictionaries in the Halich dialect. That being said, it should be noted that the dictionary does not provide information concerning its association with magic. It simply translates kasdimli as 'Chaldejczyk | a Chaldean person' (KRPS 296).

There are two terms, which are derived from the Hebrew word קוסם 'magician, bibl. sorcerer'. The first one occurs in the drama in two phonetic variants, namely qosemci and qosemçi (Мме̨тек 2012: 57b, 58b). The word qosemçi is attested by Dubiński (1994: 185) in the meaning of "przewidujący, jasnowidz | foreteller, soothsayer'. Curiously enough, in another Karaim manuscript, edited and published by Aqtay, the Hebrew word qosem (AqTAy 2009: 275) is 
used for the same denotation, without the Turkic suffix -cI, which is added to nouns in order to indicate person's profession or occupation. Although this word is not indicated in Crimean Karaim dictionaries, we encounter its derivative kösemçilik qosmaçılıq in the meaning of 'uprawianie czarów | witchcraft' (KRPS 340, 371).

Moreover, the word qosem is used to translate the Hebrew phrase מקל קסם 'magic stick' (HA-EFRATi 1829: 83a) into Turkic as qosemçilik degenegi (SмĘTEK 2012: 58a), in which qosemçilik means 'magic' and degenek 'a stick'. This term is not to be found in any other source. Dubiński provided only qosemçilik 'wróżba, przepowiadanie | divination, forecasting' (DuBIŃski 1994: 185). Therefore, it is probable that Abraham Lutski created this term while preparing the translation.

The word şzbrda- 'to chant' (Sме̨тек 2012: 58b) is not reflected in the Hebrew play. Thus, it must have been added by the translator. The term is provided in the Crimean Karaim dictionary with the meaning of 'czarowac | to bewitch' (KRPS 648). Moreover, Dubiński (1994: 183) stated that it is an onomatopoeic word whose primary meaning is 'szeptanie, szum | whispering, rustle', yet it was used by Karaims in order to denote 'czarowanie, czary | casting a magic spell, witchery'.

The following Hebrew phrase related to magic is חכםי יועצי מצרים Egyptian sages and advisers' (HA-EFrati 1829: 13b). In the tradition of reading the Bible Egyptian sages were "distinguished by magical and divinatory skills" (PERDUE 2008: 279), that is they were wizards and soothsayers. The translator must have been aware of this fact as he paraphrased it into Turkic as Misır'niñ minacimleri 'Egyptian wizards' (Sме̨тек 2012: 10a). The word minacim is a loanword from Arabic munağğim. It is attested in Dubiński's list of magical terms (1994: 186) in the meaning of 'czarodziej, przepowiadający, mędrzec | wizard, foreteller, sage'. Moreover, the word minacim is provided in the Karaim dictionary for the Crimean dialect in the same meaning, i.e. 'czarodziej | wizard' (KRPS 407).

The verb להעלות 'to raise, to reveal' (HA-EFrati 1829: 83b) is not directly related to magic. Nonetheless, it is used in the play in the meaning of 'evoking a ghost of a person who has passed away from the underworld'. It was translated quite literally into Turkic as çıqar- 'to make something or someone get 
out of somewhere' (SMĘTEK 2012: 58b). There is no evidence of an analogical usage of this word in other Karaim texts preserved in mejumas. Therefore, it is probable that the translator decided to use this Turkic word in order to literally translate the Hebrew phrase. As in the original, he used a word that was not primarily related to magic.

\section{Conclusion}

On the basis of the comparison presented above, it should be concluded that the percentage of Hebrew words used in translation of magical terms is low in this context. However, in the light of the fact that there are hardly any Hebrew loanwords in the main body of the text of the Turkic translation, their appearance in magical terminology should be considered as relatively significant.

Bibliography

Aqtay, Gülayhan. 2009. Eliyahu ben Yosef Qulci's Anthology of Crimean Karaim and Turkish Literature. İstanbul: Mehmet Ölmez Yayınları.

ÇulHA, Tülay. 2010. Kırım Karaycasının Katık Mecuması. Metin-Sözlük-Dizin. İstanbul: Mehmet Ölmez Yayınları.

DuBIŃskI, Aleksander. 1994. Terminy wróżbiarskie $w$ karaimskich przekładach Biblii. In: Tadeusz Majda (ed.). Caraimica. Warszawa: Dialog, 177-188.

Ha-Efrati, J oseph Tropplowitz. 1829. Melukhat Sha'ul ha-Melekh ha-Rishon al Yeshurun. Vienna: Anton von Schmidt.

KiziLov, Mikhail. 2009. The Karaites of Galicia: An Ethnoreligious Minority Among the Ashkenazim, the Turks, and the Slavs, 1772-1945. Leiden: Brill.

KRPS = Baskakov, N. A., A. Zajončkovskij, S. M. Šapšal (eds.). 1974. Karaimskorussko-pol'skij slovar'. Moskva: Russkij J azyk.

Perdue, Leo G. (ed.). 2008. Scribes, Sages, and Seers: The Sage in the Eastern Mediterranean World. Göttingen: Vandenhoeck \& Ruprecht.

Radloff, V.V. 1896. Proben der Volkslitteratur der Nördlichen Türkischen Stämme. Theil VII. Mundarten der Krym. St. Petersburg. 
SкоLniк, Fred (ed.). 2007. Encyclopaedia Judaica. 2nd ed. V. 8. Detroit: Macmillian Reference USA.

SмĘтек, Dorota. 2012. Crimean Karaim Version of Melukhat Sha'ul. Critical Edition and Linguistic Analysis. [unpublished doctoral thesis].

The New Revised Standard Version Bible. 1989. Division of Christian Education of the National Council of the Churches of Christ in the United States of America.

Waxman, Meyer. 1960. A History of J ewish Literature. V. 3, From the Middle of the Eighteenth Century to 1880. New York, London: Thomas Yoseloff.

ZAJĄczkowski, Ananiasz. 1946-1947. Terminologia muzułmańska a tradycje nomadów w słownictwie karaimskim. Myśl Karaimska 24: 2, 24-39.

ZAJĄCZKowsKI, Włodzimierz. 1973. Łucki Józef Salomon. In: Władysław Konopczyński [et alii, eds]. Polski Stownik Biograficzny V. 18, Part 4, 79, Polska Akademia Umiejętności, 512-513.

Dorota Smętek is a senior lecturer in the Department of Asian Studies in Adam Mickiewicz University. Her academic research is focused on Karaite studies and contemporary Turkish literature. She defended her doctoral thesis in Turkish linguistics in 2012. 
